Tugas Individu

Mata Kuliah: Matematika II

Dosen: Jusmawati,S.Pd.,M.Pd

\title{
TUGAS PENDIDIKAN MATEMATIKA II
}

VOLUME PRISMA SEGI EMPAT

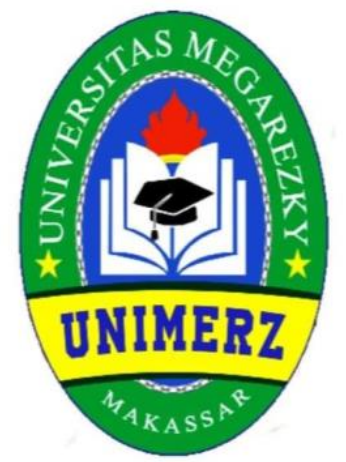

NAMA

ASTARI PUSPITA SARI

18093188206030

S1 PENDIDIKAN GURU SEKOLAH DASAR (PGSD)

FAKULTAS KEGURUAN DAN ILMU PENDIDIKAN

UNIVERSITAS MEGAREZKY

T.A 2021 


\section{KATA PENGANTAR}

Puji syukur kepada Tuhan Yang Maha Kuasa yang telah melimpahkan karunia-Nya sehingga makalah ini dapat terselesaikan dengan baik.

Penulis menyadari bahwa makalah ini masih ada kekuragan dan memerlukan perbaikan oleh sebab itu, penulis menerima kritik dan saran yang bersifat membagun untuk lebih sempurnanya makalah ini. Atas kritik dan saran yang di berikan, penulis mengucapkan terima kasih dan semoga maklah ini dapat bermanfaat bagi semua pihak.

Makassar, 06 Februari 2021

Penulis 


\section{DAFTAR ISI}

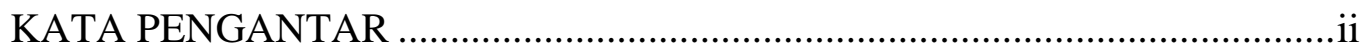

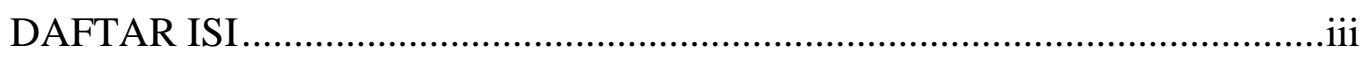

\section{BAB I PENDAHULUAN}
A. Latar Belakang ........................................................................... 1

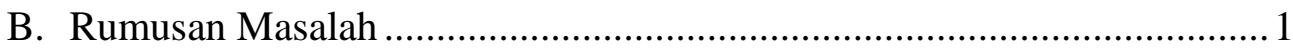

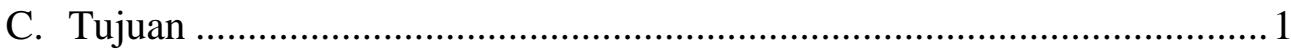

\section{BAB II PEMBAHASAN}
A. Pengertian Volume Prisma Segi Tiga .................................................. 2
B. Sifat -sifat Volume Prisma Segi Tiga ................................................... 6
C. Rumus - rumus volume prisma segi empat ....................................... 8

BAB III PENUTUP

Kesimpulan .............................................................. 16

Saran ............................................................................ 16

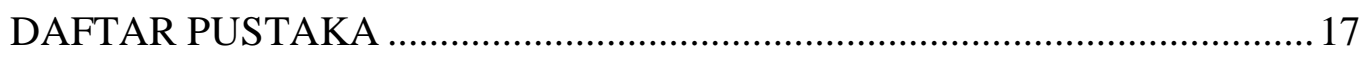




\section{BAB I}

\section{PENDAHULUAN}

\section{A. Definisi Prisma}

Nowadays the development of a more modern era in globalization is marked by the 21 st century, where every human is required to develop based on their respective expertise and knowledge. Globalization today demands human resources that are of high quality, an increase in human resources is an absolute requirement to achieve development goals (Jusmawati, $2020: 200$ )

Suatu bangun ruang yang bentuk dan ukuran sisi atas dengan sisi bawah sama serta rusuk-rusuk tegak yang sejajar disebut prisma. Sebuah bangun prisma ditentukan oleh bentuk alasnya. Maksudnya bahwa penamaan suatu prisma berdasarkan bentuk alasnya, contohnya, suatu bangun prisma yang alasnya berbentuk segitiga maka dinamakan prisma segitiga, prisma yang alasnya berbentuk segiempat maka dinamakan prisma segiempat, prisma yang alasnya berbentuk segi-lima maka dinamakan prisma segi-lima, dan seterunya.

Coba kamu perhatikan benda-benda berikut ini.

Sepotong kue dan kotak kado. Benda-benda tersebut memiliki bentuk yang sangat unik. Jika digambarkan secara geometris, benda-benda tersebut akan tampak seperti pada gambar berikut ini.Berbeda dengan kubus dan balok, bangun ruang ini memiliki kekhasan tersendiri. Coba perhatikan bangun ruang tersebut memiliki bentuk alas dan atap yang sama bentuk dan aturannya. Selain itu, semua sisi bagian samping berbentuk persegipanjang bangun ruang ini dinamakan prisma. Unsur-unsur apa saja yang dimiliki oleh prisma? Coba perhatikan prisma segienam ABCDEF.GHIJKL,. Dari terlihat bahwa prisma segienam tersebut memiliki unsur-unsur sebagai berikut.

\section{Sisi/Bidang}


Terdapat 8 sisi atau bidang yang dimiliki oleh prisma segienam, yaitu ABCDEF (sisi alas), GHIJKL (sisi atas), BCIH (sisi depan), FEKL (sisi belakang), ABHG (sisi depan kanan), AFLG (sisi belakang kanan), CDJI (sisi depan kiri), dan DEKJ (sisi belakang kiri).

\section{Rusuk}

prisma segienam ABCDEF.GHIJKL memiliki 18 rusuk, 6 di antaranya adalah rusuk tegak. Rusuk-rusuk tersebut adalah AB, BC, CD, DE, EF, FA, GH, HI, IJ, JK, KL, LG, dan rusuk-rusuk tegaknya adalah AG, BH, CI, DJ, EK, FL.

\section{Titik Sudut}

Prisma segienam ABCDEF.GHIJKL memiliki 12 titik sudut. Dari Gambar 8.19 , terlihat bahwa titik-titik sudut tersebut adalah A, B, C, D, E, F, G, H, I, J, K, dan L. Selain unsur-unsur yang telah disebutkan, prisma pun memiliki istilah diagonal bidang dan bidang diagonal. Untuk lebih jelasnya.

\section{Diagonal Bidang}

prisma segienam ABCDEF. GHIJKL pada Gambar 8.20. Dari gambar tersebut terlihat ruas garis BG yang terletak di sisi depan kanan (sisi tegak) ditarik dari dua titik sudut yang saling berhadapan sehingga ruas garis BG disebut sebagai diagonal bidang pada bidang prisma segienam ABCDEF. GHIJKL. Begitu pula dengan ruas garis CJ pada bidang CDIJ. Ruas garis tersebut merupakan diagonal bidang pada prisma segienam ABCDEF. GHIJKL. Coba kamu sebutkan diagonal bidang yang lain dari prisma segienam.

\section{Bidang Diagonal}

prisma segienam ABCDEF.GHIJKL pada Gambar 8.21 . Pada prisma segienam tersebut, terdapat dua buah diagonal bidang yang sejajar yaitu BI dan FK. Kedua diagonal bidang tersebut beserta ruas garis KI dan FB membentuk suatu bidang di dalam prisma segienam ABCDEF.GHIJKL. Bidang tersebut 
adalah bidang BFKI yang merupakan bidang diagonal prisma segienam. Coba kamu sebutkan bidang diagonal yang lain dari prisma segienam.

\section{Jaring-jaring Prisma}

Jaring-jaring prisma diperoleh dengan cara mengiris beberapa rusuk prisma tersebut sedemikian sehingga seluruh permukaan prisma terlihat. Misalkan, prisma yang akan dibuat jaring-jaringnya adalah prisma segitiga. Berikut ini adalah alur pembuatan jaring-jaring prisma segitiga. terlihat bahwa jaring-jaring prisma memiliki tiga persegipanjang sebagai sisi tegak dan dua segitiga sebagai sisi alas dan sisi atas. Berikut ini adalah berapa jaring-jaring prisma segitiga yang lain. Terdapat beberapa macam bentuk jaring-jaring prisma segitiga yang dapat dibuat. Semuanya bergantung pada cara mengiris beberapa rusuk prisma segitiga tersebut. Coba kamu tentukan bentuk jaring-jaring prisma segitiga yang lain. Sekarang, bagaimana dengan jaring-jaring prisma yang lain? Misalnya, prisma segilima atau prisma segienam. Untuk menjawabnya, coba kamu perhatikan atau pelajari

\section{Luas Permukaan Prisma}

Sama seperti kubus dan balok, luas permukaan prisma dapat dihitung menggunakan jaring-jaring prisma tersebut. Caranya adalah dengan menjumlahkan semua luas bangun datar pada jaring-jaring prisma. Coba kamu perhatikan prisma segitiga beserta jaring-jaringnya..

\section{Volume Prisma}

Untuk mengetahui rumus volume prisma, perhatikan memperlihatkan sebuah balok ABCD.EFGH yang dibagi dua secara melintang. Ternyata, hasil belahan balok tersebut membentuk prisma segitiga, seperti pada Gambar 8.26 (b). Perhatikan prisma segitiga BCD.FGH . Dengan demikian, volume prisma segitiga adalah setengah kali volume balok. 


\section{B. RUMUSAN MASALAH}

1. Untuk mengetahui Pengertian Volume Prisma Segi Tiga

2. Untuk mengetahui Model, Metode, Startegi Pendekatan yang cocok

3. Untuk mengetahui Sifat-sifat Volume Prisma Segi Tiga

\section{BAB II}

\section{PEMBAHASAN}

\section{A. Prisma Segi Empat}

Prisma memiliki definisi sebagai "sebuah hasil penggabungan antara bangun datar 2 dimensi.". Kedua bangun datar inilah yang akan membentuk prisma, dalam bentuk prisma segiempat, berarti alasnya akan berbentuk persegi dengan empat sisi, dan memiliki selimut yang berbentuk segiempat juga. Dan kalau dilihat dengan baik, prisma segiempat adalah sebutan lain untuk balok, karena memiliki bentuk yang sama Jika membahas bangun ruang memang banyak sekali jenisnya. Namun kali ini kami hanya akan membahas salah satu jenis bangun ruang, yaitu prisma. Tentunya Anda sudah tidak asing lagi jenis bangun ruang satu ini. Hal ini karena banyak sekali contoh objek atau benda yang menggunakan bentuk prisma. Seperti misalnya tenda perkemahan ataupun atau bangunan rumah. Keduanya mempunyai bentuk yang hampir menyerupai prisma segitiga.

pada pembahasan kali ini kami akan mengulas secara lengkap mengenai cara menghitung volume prisma lengkap beserta pengertian, jenis-jenis, sampai dengan contoh soalnya. Sebenarnya rumus untuk volume bangun ruang prisma ini sangat mudah dan sudah diajarkan sejak di bangku sekolah. Disini kita hanya mengulanginya dengan adanya tambahan soal sehingga akan memudahkan Anda untuk memahami materi ini. Untuk lebih jelasnya mari langsung saja simak pembahasan selengkapnya mengenai bangun ruang prisma berikut ini. 


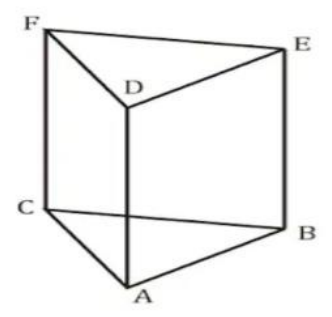

\section{Pengertian Prisma}

Prisma merupakan salah satu jenis bangun ruang yang memiliki bidang alas dan bidang atas yang saling sejajar serta kongruen. Lalu mengapa bangun ruang ini dibilang sejajar dan kongruen? Ini karena sisi lainnya merupakan sebuah sisi yang tegak dan memiliki bentuk persegi panjang atau jajargenjang.

Sama halnya dengan bangun ruang limas, prisma juga memiliki banyak sekali macam jenisnya. Beberapa diantaranya adalah bangun ruang prisma segitiga, prisma segiempat, prisma segilima, dan lain sebagainya. Perlu diketahui bahwa pengambilan nama dari macam jenis bangun ruang tersebut diambil berdasarkan bentuk alas dan juga atapnya. Jika misalnya memiliki 4 sudut maka disebut dengan prisma segiempat.

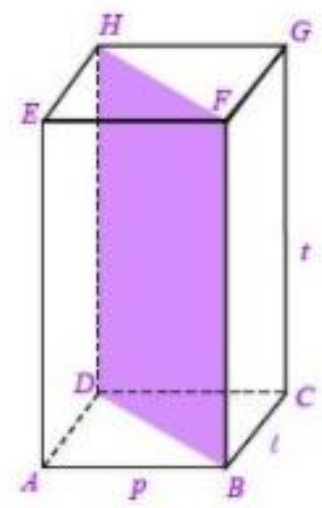

(a)

Beberapa hal yang menjadi ciri dari prisma:

- Alas dan atap memiliki bentuk yang sama/kongruen 
- Sisi bagian samping berbentuk persegi panjang atau sejajar

- Setiap diagonal bidang pada sisi yang sama

Dengan mengetahui ciri-ciri ini kamu akan lebih mudah mengetahui atau mendeteksi sebuah bangun ruang yang berbentuk prisma.

\section{B. Sifat -sifat Volume Prisma Segi Tiga}

Bangun ruang prisma memiliki beberapa sifat tertentu yang tidak dimiliki oleh bangun ruang jenis lainnya. Adapun sifat-sifat bangun ruang prisma adalah sebagai berikut ini:

- Bangun ruang prisma memiliki bentuk alas dan atap kongruennya sama atau sebangun

- Masing-masing sisi bagian samping memiliki bentuk persegi panjang atau jajargenjang

- Pada umumnya bangun ruang prisma mempunyai rusuk tegak, namun ada juga yang tidak tegak

- Masing-masing diagonal bidang pada sisi yang sama, mempunyai ukuran yang sama

\section{Rumus - rumus volume prisma segi empat}

\section{Berbagai Rumus Prisma Segi Empat}

Seperti yang sudah kita ketahui, prisma segiempat memiliki bentuk yang serupa dengan balok atau kubus, sehingga rumus yang kita gunakan untuk menghitung berbagai hal akan serupa dengan rumus yang digunakan untuk balok atau kubus

1. Rumus Luas 
Seperti yang sudah kita sebutkan di atas, dalam menghitung luas atau luas permukaan prisma segiempat, kita bisa menggunakan rumus luas balok atau kubus, jadi rumus yang akan kita gunakan adalah:

$\mathbf{L}=\mathbf{2}(\mathbf{p . l}+\mathbf{p . t}+\mathbf{l . t})$ untuk berbentuk balok

Atau

$\mathbf{L}=\mathbf{6} \times \mathbf{S} \times \mathbf{S}$ untuk berbentuk kubus

$\mathbf{P}=$ panjang

$\mathbf{L}=$ lebar

T = tinggi

2. Rumus Volume

Untuk rumus volume masih sama, kita bisa menggunakan rumus untuk menghitung volume balok atau kubus yaitu:

V = p.l.t untuk berbentuk balok

Atau

$\mathbf{V}=\mathbf{S}^{\mathbf{3}}$ untuk berbentuk kubus

$\mathbf{P}=$ panjang

$\mathbf{L}=$ lebar 


\section{T = tinggi}

3. Rumus Total Panjang Rusuk

Untuk rumus total panjang rusuk prisma segiempat, kita akan gunakan jumlah dari semua ukuran rusuk, sehingga rumus nya akan seperti ini”

$\mathbf{K}=\mathbf{4}(\mathbf{p}+\mathbf{l}+\mathbf{t})$ untuk berbentuk balok

Atau

$\mathbf{K}=\mathbf{1 2} \times \mathbf{S}$ untuk berbentuk kubus

Maka untuk setiap bangun ruang prisma berlaku rumus sebagai berikut:

- Volume prisma $=$ luas alas $\mathbf{x}$ tinggi prisma

- Jika misalnya kita ingin menentukan volume sebuah prisma maka harus mencari luas alas prisma terlebih dahulu. Untuk luas alasna dapat dicari sesuai dengan bentuk alas. Setelah itu tingga kita cari berapakah tinggi prisma.

- Apabila luas alas dan juga tinggi bangun ruang sudah diketahui maka kita bisa mencari volume bangun ruang prisma dengan cara mengalikan luas alas prisma dengan tinggi prisma. Berikut ini adalah volume bangun ruang prisma berdasarkan bentuk alas dan juga tutupnya.

\section{B. MODEL PEMBELAJARAN}

Model pembelajaran yang sesuai dengan materi volume prisma segi empat adalah matematika realistik. Model pembelajaran matematika realistik merupakan teori belajar mengajar dalam pendidikan matematika. Model pembelajaran matematika realistik 
pada dasarnya adalah pemanfaatan realitas dan lingkungan yang dialami oleh siswa untuk melancarkan proses pembelajaran matematika, sehingga mencapai tujuan pendidikan matematika yang lebih baik daripada yang lalu.

Langkah-langkah dalam proses pembelajaran volume prisma segi empat dengan menggunakan model pembelajaran matematika realistik, sebagai berikut:

1. Memahami masalah kontekstual, yaitu guru memberikan masalah kontekstual dalam kehidupan sehari-hari dan meminta siswa untuk memahami masalah tersebut.

2. Menjelaskan masalah kontekstual, yaitu jika dalam memahami masalah siswa mengalami kesulitan, maka guru menjelaskan situasi dan kondisi dari soal dengan cara memberikan petunjuk petunjuk atau au berupa saran seperlunya, terbatas pada bagian-bagian tertentu dari permasalahan yang belum dipahami.

3. Menyelesaikan masalah kontekstual, yaitu siswa secara individual menyelesaikan masalah kontekstual dengan cara mereka sendiri. Cara pemecahan dan jawaban masalah berbeda lebih diutamakan. Dengan menggunakan lembar kerja, siswa mengerjakan soal. Guru memotivasi siswa untuk menyelesaikan masalah dengan cara mereka sendiri.

4. Membandingkan dan mendiskusikan jawaban, yaitu guru menyediakan waktu dan kesempatan kepada siswa untuk membandingkan dan mendiskusikan jawaban masalah secara berkelompok. Siswa dilatih untuk mengeluarkan ide-ide yang mereka miliki dalam kaitannya dengan interaksi siswa dalam proses belajar untuk mengoptimalkan pembelajaran.

5. Menyimpulkan, yaitu guru memberikan kesempatan kepada siswa untuk menarik kesimpulan tentang suatu konsep atau prosedur.

\section{PENDEKATAN PEMEBLAJARAN}

Metode pembelajaran matematika adalah cara untuk mencapai tujuan pembelajaran matematika. Penggunaan metode yang tepat akan menentukan efektifitas dan efisiensi pembelajaran. Beberapa metode yang dapat dipilih guru matematika adalah metode ceramah, ekspositori, demonstrasi, tanya jawab, penugasan, eksperimen, drill dan latihan, penemuan inquiry, permainan dan pemecahan masalah. 


\section{Metode Ceramah}

Metode ceramah pada umumnya yaitu, suatu cara penyampaian informasi dengan lisan dari seseorang kepada sejumlah pendengar di suatu ruangan. Maka metode ceramah dalam pembelajaran matematika adalah suatu cara penyampaian bahan / materi matematika kepada peserta didik melalui komunikasi lisan oleh pendidik di dalam kelas.

Keunggulan yang dimiliki dalam metode ceramah yaitu:

1) Ceramah merupakan metode yang mudah dan murah artinya dapat menampung jumlah siswa yang banyak tanpa memerlukan peralatan-peralatan yang lengkap dan siswa mempunyai kesempatan untuk mendengarkan karena biaya yang diperlukan relatif lebih kecil.

2) Konsep yang disajikan secara hirarki akan memberikan fasilitas belajar kepada siswa.

3) Fleksibel : jika waktu sedikit bahan dipersingkat, diambil yang pentingpenting saja, jika waktu banyak dapat disampaikan sebanyak-banyaknya.

4) Guru dapat memberikan tekanan-tekanan terhadap hal-hal yang penting hingga waktu dan energi dapat digunakan sebaik mungkin.

5) Guru dapat menguasai seluruh kelas dengan mudah, walaupun jumlah murid cukup banyak.

6) Isi silabus dapat diselesaikan dengan lebih mudah, karena guru tidak harus menyesuaikan dengan kecepatan belajar siswa.

7) Kekurangan atau tidak adanya buku pelajaran dan alat bantu pelajaran tidak menghambat dilaksanakannya pelajaran.

8) Organisasi kelas dapat diatur menjadi lebih sederhana karena tidak memelukan setting yang beragam.

2.Metode Ekspositori 
Metode ekspositori adalah metode pembelajaran yang digunakan dengan memberikan terlebih dahulu defenisi, prinsip dan konsep materi pelajaran serta memberikan contoh-contoh latihan pemecahan masalah. David P.Ausubel menyebutkan bahwa metode ekspositori merupakan cara mengajar yang paling efektif dan efisien dalam menanamkan belajar bermakna. Auseubel membedakan belajar menjadi : Belajar dengan menerima (reception learning) dan Belajar melalui penemuan (discovery learning). Belajar juga dibedakan menjadi dua: Belajar dengan menghafal (rote learning) dan Belajar dengan pengertian (meaningful learning)

\section{Metode Demonstrasi}

Metode demonstrasi adalah metode penyajian pembelajaran dengan memperagakan dan mempertunjukkan kepada siswa tentang suatu proses, situasi atau benda tertentu baik sebenarnya atau hanya sekedar tiruan-tiruan yang sering disertai dengan penjelasan lisan.

\section{STARTEGI PEMBELAJARAN}

\section{Strategi Inkuiri}

Strategi inkuiri berarti suatu rangkaian kegiatan kegiatan belajar yang melibatkan secara maksimal seluruh kemampuan siswa untuk mencari dan menyelidiki secara sistematis, kritis, logis, analitis, sehingga mereka dapat merumuskan sendiri penemuannya denga penuh percaya diri. Sasaran utama kegiatan mengajar pada strategi ini ialah:

a. Keterlibatan siswa secara maksimal dalam proses kegiatan belajar. Kegiatan belajar di sini adalah kegiatan mental intelektual dan sosial emosional.

b. Keterarahan kegiatan secara logis dan sistematis pada tujuan pengajaran

c. Mengembangkan sikap percaya pada diri sendiri (selfbelief) pada diri siswa tentang apa yang ditemukan dalam proses inkuiri. 
2. Strategi Penyelesaian Masalah (PROBLEM SOLVING) Strategi belajar mengajar penyelesaian masalah memberi tekanan pada terselesaikannya suatu masalah secara menalar. Proses ini berlangsung secara bertahap, mulai dari menerima stimulus dari lingkungan sampai pada memberi respons yang tepat terhadapnya. Penyelesaian masalah dapat dilakukan dengan berbagai cara antara lain : a. Penyelesaian masalah berdasarkan pengalaman masa lampau, dalam hal ini penyelesaian masalah kurang (tidak) rasional. b. Penyelesaian masalah secara intuitif masalah diselesaikan tidak berdasarkan akal, tetapi berdasarkan intuisi atau firasat. c. Penyelesaian masalah dengan cara trial error, penyelesaian masalah dilakukan dengan coba-coba ,percobaan yang dlakukan tidak berdasar hipotesis tetapi secara acak. d. Penyelesaian masalah secara otoritas. Penyelesaian masalah dilakukan berdasarkan kewenangan seseorang. e. Penyelesaian masalah secara meta fisik. Masalah-masalah yang dihadapi dalam dunia empirik diselesaikan dengan prinsip-prinsip yang bersumber pada dunia supranatural/dunia mistik/dunia gaib.

f. Penyelesaian masalah secara ilmiah ialah penyelesaian masalah secara rasional melalui proses deduksi dan induksi. Penyelesaian masalah dalam strategi belajar mengajar disini ialah penyelesaian masalah secara ilmiah atau semi ilmiah. Guru memilih bahan pelajaran yang memiliki permasalahan, materi pelajaran tidak terbatas hanya pada buku teks disekolah tetapi dapat diambil dari sumber-sumber lingkungan yang ada. 


\section{Contoh Soal Prisma Segi Empat}

1. Sebuah prisma tegak segiempat memiliki alas berupa persegi dengan panjang sisi $7 \mathrm{~cm}$. Tingginya $12 \mathrm{~cm}$. Berapakah volume prisma tegak segiempat tersebut?

2. Sebuah prisma tegak segiempat dengan alas berupa persegi panjang dengan panjang $4 \mathrm{~cm}$, lebar $6 \mathrm{~cm}$, dan tinggi $10 \mathrm{~cm}$. Berapakah volumenya?

3. Sebuah limas mempunyai alas berbentuk persegi dengan panjang sisinya $8 \mathrm{~cm}$. Hitung volume limas, jika tingginya $11 \mathrm{~cm}$.

4. Limas segiempat T. PQRS. Alasnya PQRS berbentuk persegi panjang. Panjang 5 $\mathrm{cm}$ dan lebar $6 \mathrm{~cm}$ serta tinggi limasnya $10 \mathrm{~cm}$. Berapakah volume limas tersebut?

\section{Diketahui : Panjang alas : $7 \mathrm{~cm}$}

: Tinggi : $12 \mathrm{~cm}$

Ditanya : Volume prisma?

Penyelesaian :

Luas alas : $\mathrm{s} \mathrm{x} \mathrm{s}=7 \mathrm{~cm} \times 7 \mathrm{~cm}=49 \mathrm{~cm}^{2}$

$\mathrm{V} \quad$ : luas alas $\mathrm{x}$ tinggi

$: 49 \mathrm{~cm}^{2} \times 12 \mathrm{~cm}$

$: 588 \mathrm{~cm}^{3}$

2. Diketahui :

Panjang alas : $5 \mathrm{~cm}$

Lebar alas $\quad: 6 \mathrm{~cm}$

Tinggi $\quad: 10 \mathrm{~cm}$

Ditanya : Volume prisma?

Penyelesaian : 
Luas alas $\quad: \mathrm{p} \times 1$

$: 5 \mathrm{~cm} \times 6 \mathrm{~cm}$

$: 30 \mathrm{~cm}^{2}$

$\mathrm{V}$ : luas alas $\mathrm{x}$ tinggi

$: 30 \mathrm{~cm}^{2}$ x $10 \mathrm{~cm}$

$: 300 \mathrm{~cm}^{3}$

3. Diketahui : Panjang alas $: 9 \mathrm{~cm}$

: Tinggi $\quad: 6 \mathrm{~cm}$

Ditanya : Volume limas?

Penyelesaian :

Luas alas : $\mathrm{s} \mathrm{x} \mathrm{s}=9 \mathrm{~cm} \times 9 \mathrm{~cm}=81 \mathrm{~cm}^{2}$

$\mathrm{V} \quad: 1 / 3 \mathrm{x}$ luas alas $\mathrm{x}$ tinggi

$: 1 / 3 \times 81 \mathrm{~cm}^{2} \times 6 \mathrm{~cm}$

$: 27 \mathrm{~cm}^{2} \times 6 \mathrm{~cm}$

$: 162 \mathrm{~cm}^{3}$

4. Diketahui :

Panjang alas : $5 \mathrm{~cm}$

Lebar alas $\quad: 6 \mathrm{~cm}$

Tinggi $\quad: 10 \mathrm{~cm}$

Ditanya : Volume limas?

Penyelesaian :

Luas alas $\quad: \mathrm{p} \times 1$

$: 5 \mathrm{~cm} \mathrm{x} 6 \mathrm{~cm}$

$: 30 \mathrm{~cm}^{2}$ 
$\mathrm{V}: 1 / 3 \mathrm{x}$ luas alas $\mathrm{x}$ tinggi

$: 1 / 3 \times 30 \mathrm{~cm}^{2} \times 10 \mathrm{~cm}$

$: 10 \mathrm{~cm}^{2} \times 10 \mathrm{~cm}$

$: 100 \mathrm{~cm}^{3}$ 


\title{
Rencana Pelaksanaan Pembelajaran
}

\section{(RPP)}

\author{
Satuan Pendidikan : Sekolah Dasar \\ Kelas/semester $\quad:$ VI / 1 \\ Mata pelajaran $\quad$ : Matematika \\ Jumlah pertemuan $\quad: 1 \mathrm{x}$ pertemuan
}

A. Standar Kompetensi / Kompetensi inti

- Menerima dan menjalankan ajaran agama yang dianutnya

- Menunjukkan perilaku jujur, disiplin, tanggung jawab, santun, peduli, dan percaya diri dalam berinteraksi dengan keluarga, teman, dan guru

- Memahami pengetahuan faktual dengan cara mengamati (mendengar, melihat, membaca) dan bertanya berdasarkan rasa ingin tahu tentang dirinya, makhluk ciptaan Tuhan dan kegiatannya, dan benda-benda yang dijumpainya di rumah dan di sekolah

- Menyajikan pengetahuan faktual dalam bahasa yang jelas dan logis dan sistematis dalam karya yang estetis, dalam gerakan yang mencerminkan anak sehat, dan dalam tindakan yang mencerminkan perilaku anak beriman dan berakhlak mulia

B. Kompetensi Dasar

4.1 Menghitung volume prisma segiempat

C. Indikator Pencapaian Kompetensi

a) Menjelaskan volume prisma segiempat

b) Menghitung volume prisma segiempat

c) Menjelaskan penggologan prisma segiempat 
D. Tujuan Pembelajaran

Setelah kegiatan pembelajaran siswa dapat :

1) Menjelaskan pengertian volume prisma segiempat

2) Mampu menghitung volume prisma segiempat

3) Mampu menggolongkan prisma segi empat

4) Karakter siswa yang di harapkan : kompak, saling membantu, tanggung jawab, rasa hormat, dan tekun

E. Materi Pembelajaran

a. Volume prisma segiempat

b. Gambar macam - macam bangun ruang

F. Metode Pembelajaran

1) Demonstrasi

2) Latihan

3) Tanya jawab

G. Kegiatan Pembelajaran

a) Kegiatan Pendahuluan

1) Salam

2) Doa

3) Memeriksa kebersihan/ perlengkapan kelas/ kesiapan siswa

4) Absensi

5) Apersepsi (menanyakan isi materi yang lalu)

6) Informasi materi dan tujuan pembelajaran pelajaran yang akan disampaikan.

b) Kegiatan Inti 
1) Guru meminta siswa untuk menyebutkan benda-benda yang berbentuk prisma segiempat yang berada di lingkungan sekitar.

2) Guru mempersiapkan media pembalajaran berupa prisma segiempat Guru meminta salah seorang siswa untuk maju kedepan memasukkan kubus-kubus satuan kedalam wadah kaca prisma segiempat.

3) Guru meminta siswa menghitung jumlah kubus satuan yang ada didalam wadah kaca prisma segiempat.

4) Guru bersama siswa menunjukan panjang, lebar dan tinggi pada prisma segiempat.

5) Siswa di minta maju kedepan untuk menghitung panjang, lebar dan tinggi prisma segiempat.

6) Guru bersama siswa menentukan rumus prisma tegak segiempat.

7) Guru meminta seorang siswa maju kedepan mengerjakan contoh soal.

8) Guru meletakkan media bangun ruang prisma segi empat di atas meja.

9) Siswa diingatkan kembali mengenai rumus bangun ruang prisma segiempat yang telah dipelajari.

10) Guru mengajak 2 orang siswa maju ke depan kelas, 1 orang siswa di minta untuk memegang bangun ruang segiempat dan 1 orangnya memasukkan beras yang berwarna merah ke dalam bangun ruang limas tersebut kemudian mencurahkan beras tersebut ke dalam prisma tegak segiempat.

11) Kemudian guru menyuruh secara bergantian 2 orang siswa lagi untuk maju kedepan, 1 orang memegang bangun ruang limas dan 1 orangnya lagi memasukkan beras berwarna kuning ke dalam bangun ruang limas kemudian mencurahkan beras tersebut ke dalam prisma segi empat.

12) Guru kemudian membimbing siswa menemukan rumus dari volum limas segiempat

13) Guru membimbing siswa cara menurunkan rumus volume bangun ruang melalui percobaan yang telah dilakukan.

14) Guru meminta salah satu siswa mengerjakan contoh soal di depan kelas.

c) Kegiatan Penutup 
1) Guru bersama siswa menyimpulkan materi pelajaran

2) Penilaian (guru memberikan soal berdasarkan urutan tujuan pembelajaran). tidak boleh PR dan langsung dikumpulkan.

3) Guru melakukan refleksi dan tindak lanjut

4) Guru menutup kegiatan pembelajaran.

H. Alat /media dan Sumber Belajar

1) Kubus satuan

2) Wadah kaca bebrbentuk prisma tegak segiempat

3) Beras warna warni

4) Wadah kaca berbentuk limas segiempat

5) KTSP TIM BSNP. 2006. Standar isi kurikulum KTSP untuk SD/MI. Jakarta: Depdiknas.

6) Mangatur, Jautar M dan Sarman. 2007. Cerdas Bersama Matematika. Jakarta: Ganeca Exact

I. Penilaian Pembelajaran

1. Penilaian : Penilaian hasil

2. Jenis tes : Tertulis

3. Bentuk tes : Essay

Pedoman penskoran

Apabila murid menjawab semua soal dengan benar maka akan memperoleh nilai 100. Setiap soal bernilai 25 .

NILAI AKHIR $=\quad$ X 100 
Makassar, 07 Februari 2021

Kepala Sekolah

Guru Kelas 


\section{BAB III}

\section{PENUTUP}

\section{Kesimpulan}

Suatu bangun ruang yang bentuk dan ukuran sisi atas dengan sisi bawah sama serta rusuk-rusuk tegak yang sejajar disebut prisma. Sebuah bangun prisma ditentukan oleh bentuk alasnya. Maksudnya bahwa penamaan suatu prisma berdasarkan bentuk alasnya,

\section{Saran}

Dalam penulisan makalah ini, masih banyak kekurangan kekurangan maka dari itu, penulis mengharapkan semoga para pembaca bisa memberikan masukan kepada penulis. Semoga makalah ini dipergunakan sebaik-baiknya.

\section{DAFTAR PUSTAKA}

Ahmad Syukur. 2012. Bangun Ruang Prisma. (online)(http://matematika.com, diakses tanggal 7 November 2012)

Crayonpedia. 2012. Kubus, Balok, Prisma Tegak, dan Limas, (online)(http://www.crayonpedia.org, diakses tanggal 7 November 2012) 
Jusmawati, J., Satriawati, S., Rahim, I., Rahman, A., \& Arsyad, N. (2020). Developing Worksheets Through Creative Problem Solving (CPS) Model to Improve Students' Creative Thinking for the Class V of SD Tunas Bangsa Makassar. Daya Matematis: Jurnal Inovasi Pendidikan Matematika, 8(3), 200-204. 